\title{
TOEGEPASTE WETENSCHAP IN DE BRANDING
}

\author{
DOOR
}

\author{
N. H. SWELLENGREBEL
}

De eisen die de practijk stelt zijn voor de toegepaste wetenschap de stimulans, welke de vragen die de werkhypothese suggereert voor de zuivere wetenschap zijn. Is aan die eisen voldaan dan loopt het onderzoek dood - tenzij de practijk aan het resultaat der onderzoekingen nieuwe eisen ontleent: naar analogie van een nieuwe hypothese steunend op feiten die men, geleid door een oudere hypothese, al eerder had opgespoord. Ik wil hiervan een voorbeeld geven: zowel van het doodlopen ener reeks onderzoekingen, als van haar resuscitatie.

Het eerste stuk van mijn voorbeeld is bekend. Ik zal daar slechts zoveel van in herinnering brengen als voor het tweede stuk nodig is.

Het begint met Ross' ontdekking van de ontwikkeling der menselijke Plasmodia in de „dappled winged mosquito", kort daarna als een vertegenwoordiger van het geslacht Anopheles herkend.

De volgende stap zetten Stephens en Christophers, door twee dingen te vinden: (a) Vele Anopheles-soorten zijn experimenteel met menselijke Plasmodia te besmetten, maar in de natuur vindt men slechts enkele dier soorten als dragers van deze malaria parasieten; (b) Alle Anopheles-soorten zijn als larven en poppen waterdieren, maar de aard der wateren waarin ze leven (de broedplaatsen) is voor elke soort min of meer specifiek.

Watson deed de derde stap, door het voorafgaande in practijk te brengen. Dat komt hierop neer, dat men bij malariabestrijding niet alle Anophelesbroedplaatsen heeft onschadelijk te maken. Men kan zich beperken tot die der werkelijk gevaarlijke Anopheles-soorten - vaak niet meer dan één in elk afzonderlijk malaria gebied. Geeft die ene soort dan nog de voorkeur aan een bepaald type van broedplaats dan kan men dáárop alle materiële en financiële hulpmiddelen concentreren, de rest laten lopen, en zo het gehele project uitvoerbaar maken. Dat heet species-assainering.

De vierde stap is de rechtvaardiging - achteraf - van de species-assainering tegenover twee bezwaren: (a) Geen species-assainering zonder constante Anopheles-soorten; die soorten verschillen echter zóó weinig van elkaar, dat men niet mag aannemen dat ze sexueel geïsoleerd, en dus constant, zullen 
blijven - als ze dat ooit geweest zijn; (b) Geen species-assainering zonder specifïeke broedplaatsen. Die broedplaatsen onderscheiden zich echter zó weinig van elkaar, dat men mag aannemen dat de adaptabiliteit van de larven van elke Anopheles-soort groot genoeg is om haar te veroorloven zich in een andere broedplaats te ontwikkelen, indien haar voorkeurs-broedplaats niet meer bestaat. Het bezwaar van afwezigheid van sexuele isolatie werd door de onderzoekingen van $\mathrm{DE}$ Buck e.a. ontzenuwd. Zij toonden juist het bestaan dezer isolatie aan, en dat nog wel t.a.v. ondersoorten van Anopheles maculipennis. Het bezwaar van de adaptabiliteit van Anopheleslarven aan vreemde broedplaatsen werd o.a. door Schüffner en WALCH weerlegd. Zij namen de voorkeurs-broedplaatsen van de zoetwater-vorm en de brakwater-vorm van $A$. sundaicus weg, en zagen toen deze soort uit de betrokken landstreek verdwijnen.

De laatste stap maakte een einde aan de opvatting dat Anopheles-bestrijding practisch op larvenbestrijding neerkomt. In Mandailing begon ScHüFFNER met de vernietiging van imagines ( $A$. sundaicus) in woningen. Maar de uitvinding der pyrethrum-insecticieden maakte deze methode eerst practisch uitvoerbaar. Het principe der species-assainering - in ruimere zin, weliswaar - behield daarbij zijn volle betekenis. Dat kwam vooral in Noord-Holland duidelijk uit, waar deze methode pas bruikbaar werd nadat VaN THIEL e.a. er de ondersoorten van $A$. maculipennis ontdekt hadden.

Deze stap bereidde de weg voor de toepassing van het nieuwe insecticied, het D.D.T. Hiermede kom ik aan mijn tweede stuk.

De species-assainering was een zeer verfijnd instrument, dat slechts in geoefende handen zijn werk kon doen - en zelfs dan nog kon falen. In NoordHolland, bijvoorbeeld, had zij één ondersoort van $A$. maculipennis tot object. En dat nog maar alleen in het stadium waarin die ondersoort werkelijk malaria kon overbrengen: de imago, en op de plaats en in de periode waar en waarin zij dat werkelijk deed: bepaalde huizen, in nazomer en vroege herfst. Het uitzoeken van die „bepaalde huizen” eiste een exploratie-techniek welke in de loop der jaren steeds meer volmakt moest worden. Deze selectie was nodig, omdat de vernietiging der imagines in de woningen in eerste instantie tussen I en I5 Augustus uitgevoerd, en dan vier of vijf keer om de twee weken herhaald moest worden. Men beschikte namelijk over een insecticied (pyrethrum) dat de in het huis aanwezige muskieten wel onmiddellijk doodde, maar daarna het huis niet beschermde tegen anderen, die er na de bespuiting binnen kwamen. Alle huizen van een dorp (en, a fortiori, van een stad) op die wijze te behandelen was practisch niet uitvoerbaar, vanwege de korte tijd waarover men beschikte. Begon men de eerste bewerking vóór I Augustus, dan doodde men slechts onbesmette imagines; kwam men I5 Augustus met de eerste ronde niet gereed, dan ontsnapten besmette muskieten de behandeling vóór de tweede ronde begon. 
Al die moeilijkheden zijn nu door D.D.T. opgeheven. Rustig kan men de huizen hiermede behandelen wanneer nog niet één besmette Anopheles erin verblijf houdt. Want het effect der behandeling duurt minstens zes maanden, en één behandeling per jaar is practisch voldoende. Men hoeft dus geen huizen meer uit te zoeken : ze krijgen alle hun beurt. Het doet er ook geheel niet meer toe welke ondersoorten, soorten of geslachten van insecten men treft. Men vernietigt ze eenvoudig alle, voor zover ze zich in enig huis of stal ophouden. En daarmede haalt men een streep door al het werk dat de speciesassainering voorbereidde en opbouwde. Het heeft geen betekenis meer.

Het voorgaande had betrekking op de zgn. .,paint spraying”, het aanbrengen van een dunne laag (ca. 2 gm. per $\mathrm{m}^{2}$ ) D.D.T.-kristallen op de inwendige oppervlakten der gebouwen. Als men hiermede malaria denkt te bestrijden, dan neemt men aan dat Anopheles (I) de mens binnenshuis steekt, (2) vóór of ná het steken enige tijd op de wand gaat zitten. De palae- en nearctische ondersoorten van $A$. maculipennis voldoen aan deze eisen. Maar men weet volstrekt niet of alle Anopheles-soorten dat doen. Vooral die waarvan men 's morgens slechts enkelen op de wanden terug kan vinden hebben 's nachts misschien geheel niet in huis gerust, en hebben zich zo aan het contact met D.D.T. onttrokken. In Indonesië bestaan enige van die half gedomesticeerde soorten, Anopheles aconitus, $A$. punctulatus en $A$. maculatus, alle belangrijke overbrengers der malaria. De eerste wordt in met D.D.T. behandelde woningen 's ochtends geregeld dood gevonden, in een aantal dat vrijwel overeenkomt met dat der levende $A$. aconitus, dat men terzelfder tijd in de onbehandelde huizen 'vangt. Van $A$. punctulatus vindt men meer doden in de behandelde huizen, dan levenden in de onbehandelde: blijkbaar blijft deze soort wel kort in huis, maar gaat na het steken toch nog even op de wand zitten. Ik noem deze hleinigheden om te laten zien dat zekere gedragingen der Anopheles-soorten, die vroeger geen aandacht trokken, nu, in verband met D.D.T., in eens heel belangrijk worden, en dat de kennis dienaangaande zeer onvoldoende is.

Dit blijkt ook als men vraagt waar de mens door Anopheles gestoken wordt: in huis of buitenshuis.

Vele muskieten steken buitenshuis. Maar A. maculipennis doet dat niet. Daarom is zij zulk een ideaal object voor D.D.T. Van de andere Anophelessoorten weet men op dit gebied echter veel minder. Van de drie bovengenoemde half-gedomesticeerde soorten, waarvan men met moeite, of geheel niet, imagines in huizen kan verzamelen, is bekend dat men er 's avonds, buiten, vele kan vangen op mensen of vee, die als lokaas dienst doen. Maar slechts van $A$. punctulatus is bekend dat de kans op malariabesmetting buitenshuis driemaal zo groot is als binnenshuis, en dat men dus met paint spraying de malaria-frequentie voor niet meer dan één derde zal kunnen verminderen. 
Die onvoldoende kennis komt ook tot uiting als men de vraag moet beantwoorden of het zin heeft enkele huizen te behandelen, ter bescherming van de daarin gelegerde soldaten, terwijl alle andere huizen van het malaria-dorp onbehandeld blijven. Bij gebrek aan beter luidt het antwoord: Ja, als het om een Anopheles ( $A$. aconitus) gaat die men in behandelde huizen dood vindt zonder vers bloed in haar maag. Want die gaat blijkbaar eerst op de wand zitten en dan pas steken; als die wand D.D.T. draagt komt de muskiet niet meer aan steken toe, en kan dus niemand in dat huis besmetten. Maar als de dode miskieten ( $A$. punctulatus, $A$. subpictus) vers bloed in haar maag hebben, dan staken ze eerst en gingen pas daarna zitten, dan hebben ze de besmetting voor haar dood toch nog aan de menselijke bewoners kunnen overdoen, en dan heeft de behandeling met D.D.T. van enkele woningen in een malariadorp géén zin.

Zo heeft dus de inval welke D.D.T. in de practijk der malaria-bestrijding heeft gedaan op sommige plaatsen een geheel systeem van fundamentele onderzoekingen, en daarop gebaseerde maatregelen, overbodig resp. obsoleet gemaakt. Maar op andere plaatsen blijft de nieuwe methode naar kennis van de levensgewoonten der Anopheles-soorten vragen. Men kan evengoed instemmen met SOPER's triomphantelijke uitlating dat de ,malariologie" een overwonnen standpunt is, als met Muirhead Thomson's verzuchting dat men met zijn kennis eigenlijk nog niet aan D.D.T. toe is. Het komt er maar op aan welke Anopheles-soorten men voor zich heeft. 